\title{
Glucose and Xylose Productions From Oil Palm Empty Fruit Bunch by Hydrolysis With Enzyme and Acid Using Response Surface Methodology.
}

\author{
Santat Sinjaroonsak ( $\sim$ santat.s@pnu.ac.th ) \\ Princess of Naradhiwas University https://orcid.org/0000-0002-5937-6358 \\ Aran H-Kittikun \\ Prince of Songkla University https://orcid.org/0000-0001-6383-7973 \\ Thanongsak Chaiyaso \\ Chiang Mai University https://orcid.org/0000-0003-2835-5578 \\ Wasana Suyotha \\ Prince of Songkla University https://orcid.org/0000-0003-3755-2880
}

\section{Research Article}

Keywords: cellulase, glucose, hydrochloric acid, hydrolysis, oil palm empty fruit bunch, xylose

Posted Date: August 11th, 2021

DOl: https://doi.org/10.21203/rs.3.rs-768878/v1

License: (c) (i) This work is licensed under a Creative Commons Attribution 4.0 International License. Read Full License 


\section{Abstract}

Oil palm empty fruit bunch (EFB) is a major cellulosic waste from a palm oil mill. The use of EFB for bioconversion to fuel and valuable products is possible because this biomass is a cheap, renewable and abundantly available. This study was aimed to produce sugars from the alkaline peroxide pretreated EFB (APEFB) by hydrolysis with a commercial enzyme (iKnowzyme acid $2 \mathrm{XL}$ cellulase) in comparison with hydrochloric acid. Response surface methodology (RSM) was applied to improve the hydrolysis process. For an enzymatic hydrolysis, the optimum enzyme dose of $40 \mathrm{U} / \mathrm{g}$ APEFB and the liquid to solid ratio of 10 $\mathrm{ml} / \mathrm{g}$ APEFB were investigated at $150 \mathrm{rpm}$ and $50^{\circ} \mathrm{C}$ for $120 \mathrm{~h}$. After saccharification, glucose and xylose obtained were 65.71 $\mathrm{g} / \mathrm{l}(0.66 \mathrm{~g} / \mathrm{g} \mathrm{APEFB})$ and $2.14 \mathrm{~g} / \mathrm{l}(0.02 \mathrm{~g} / \mathrm{g}$ APEFB), respectively. Many acids (acetic, formic, hydrochloric (HCl), nitric, orthophosphoric and sulfuric acids) were used to hydrolyze APEFB. The result showed that $\mathrm{HCl}$ was the best acid to produce glucose and xylose from APEFB with low furfural and hydroxymethylfurfural productions. The optimum $\mathrm{HCl}$ concentration and temperature for APEFB saccharification were $5.85 \%(\mathrm{w} / \mathrm{v})$ acid at $114^{\circ} \mathrm{C}$ for $90 \mathrm{~min}$. The glucose, xylose, furfural, and hydroxymethylfurfural obtained under these conditions were $10.70 \mathrm{~g} / \mathrm{l}(0.11 \mathrm{~g} / \mathrm{g}$ APEFB), $15.30 \mathrm{~g} / \mathrm{l}(0.15 \mathrm{~g} / \mathrm{g}$ APEFB), $2.34 \mathrm{~g} / \mathrm{l}$ $(0.02 \mathrm{~g} / \mathrm{g}$ APEFB) and $0.67 \mathrm{~g} / \mathrm{l}(0.007 \mathrm{~g} / \mathrm{g}$ APEFB), respectively.

\section{Novelty}

This report shows that the cheap carbon source from empty fruit bunch can be used for sugar productions replacing the commercial carbon source. It can be reduced the cost of an expensive substrate as well as can be reduced the waste from palm oil industry. Moreover, the sugar production by using agro-industrial wastes will be helpful and beneficial to the environment. EFB can be used as a potential source for glucose and xylose productions which could be fuether used for the biorefinery process to produce biofuel and value chemicals.

\section{Introduction}

Recently, the depletion of the fossil fuel stock in the world has occurred. The utilizing of biomass as a raw material for the production of renewable energy is needed. Lignocellulosic biomass is the most abundant renewable materials on earth. The conversion of lignocellulosic waste feedstocks to value products such as chemicals and fuels has been reported. It is a clean and green technology which is renewable, low cost and intensive in nature [1-3].

Palm oil is one of the most important agricultural products of Southeast Asian countries. In general, the basic palm oil processing operations have a lot of wastes including of 11-13\% palm pressed fiber (PPF), $20-28 \%$ empty fruit bunch (EFB) and palm oil mill effluent (POME) 0.6-1.05 $\mathrm{m}^{3}$ ton $^{-1}$ fresh fruit bunch (FFB) [4-6]. EFB mainly composed of cellulose 35-59\%, hemicellulose $21-28 \%$, and lignin 11-26\% [7-10]. Previously, EFB had a little commercial value and became a disposable problem because of the bulk density thus occupying large storage volume [8]. A little amount of EFB has been used as a composting material by the landfilling method, which is very costly $[11,12]$. In addition, it is largely being burned instead of being used productively, thus causes environmental pollution [13-15].

EFB may serve as a potential raw material for the productions of chemical and energy following the concept of biorefinery. One possible approach towards the utilization of EFB is to hydrolyze into fermentable sugars and is further converted into ethanol and other value-added products. Many researchers had been utilized EFB to produce many materials such as activated carbon, bio-oil, citric acid, composting, enzymes, sugars, paper pulp and ethanol [9, 10, 16-23].

The conversion of EFB to fermentable sugars required an initial delignification pretreatment followed by hydrolysis by a chemical method or an enzymatic method. Hydrolysis of cellulose produces mostly glucose whereas hydrolysis of hemicellulose produces mostly xylose. These sugars are generally used in separate fermentation process for a production of valuable products. In this study, glucose and xylose productions from the pretreated EFB was optimized by hydrolysis with the commercial enzyme (iKnowzyme acid 2XL cellulase) and acids using response surface methodology with the central composite design. 


\section{Materials And Methods}

\section{Raw material and pretreatment}

EFB was supplied by Thai Tallow and Oil Co., Ltd., Surat Thani, Thailand. The EFB biomass was prepared by sun-drying and grinding to a particle size of $2 \mathrm{~mm}$. The pretreatment was done by soaking $50 \mathrm{~g}$ EFB in the solution of $15 \%(\mathrm{w} / \mathrm{w}) \mathrm{NaOH}$ with $3 \%$ $(\mathrm{v} / \mathrm{v}) \mathrm{H}_{2} \mathrm{O}_{2} 500 \mathrm{ml}$ for $4 \mathrm{~h}$ and then autoclaving for $5 \mathrm{~min}$ at $121^{\circ} \mathrm{C}$ [10]. After cooling, the matterials were neutralized by washing with tap water several times and rinsed in distilled water. After that, the pretreated EFB were dried at $105^{\circ} \mathrm{C}$ for $8 \mathrm{~h}$. The alkaline peroxide pretreated EFB was storred in a plastic bag and kept at room temperature until use. The compositions of cellulose, hemicellulose, and lignin in the alkaline peroxide pretreated EFB were $74.46,15.72$ and $6.40 \%(w / w)$, respectively [9].

\section{Chemicals and enzyme}

Hydrochloric acid (37\%), nitric acid (95\%) and sulfuric acid (96\%) were purchased from ACI Labscan Ltd., Bangkok, Thailand. Acetic acid (99\%), formic acid (99\%) and orthophosphoric acid (85\%) were purchased from Ajax Finechem Pty. Ltd., Australia. iKnowzyme acid 2XL cellulase was obtained from Reach Biotechnology Co. Ltd, Bangkok, Thailand.

\section{Enzyme assay and protein determination}

The activity of cellulase was determined by adding $0.5 \mathrm{ml}$ of enzyme source to $1.0 \%$ carboxymethylcellulose (CMC) (Fluka) in $0.5 \mathrm{ml}$ of $50 \mathrm{mM}$ sodium acetate buffer ( $\mathrm{pH} 5.0)$ and incubated by shaking at $500 \mathrm{rpm}$ and $50^{\circ} \mathrm{C}$ for $10 \mathrm{~min}$. The quantity of the liberated reducing sugars was measured by the DNS method [24] using glucose as a standard. One unit of the cellulase was assayed as the amount of enzyme that liberated one micromole of glucose equivalent per minute under the experimental settings. The activity of xylanase was determined by preparing $0.5 \%(\mathrm{w} / \mathrm{v})$ beechwood xylan (Sigma) dissolved in $50 \mathrm{mM}$ sodium acetate buffer ( $\mathrm{pH}$ 5.0) $0.5 \mathrm{ml}$. The amount of reducing sugar released after shaking at $500 \mathrm{rpm}$ and $50^{\circ} \mathrm{C}$ for $10 \mathrm{~min}$ was evaluated by DNS method [24] and xylose was used as a standard. One unit of xylanase activity was described as the amount of enzyme that released one micromol of xylose under the assay conditions. Protein content was determined by the Lowry method [25] using bovine serum albumin (BSA) as a standard.

\section{Enzymatic hydrolysis}

The time cause of an enzymatic hydrolysis of APEFB was carried out in a $250 \mathrm{ml}$ flask in an incubator shaker at $150 \mathrm{rpm}$ and $50^{\circ} \mathrm{C}$ for $120 \mathrm{~h}$. In the typical hydrolysis reaction, $5 \mathrm{~g}$ of the APEFB was added to $45 \mathrm{ml} 50 \mathrm{mM}$ acetate buffer pH 5.0 with Tween $800.3 \mathrm{~g} / \mathrm{l}$ and potassium metabisulfite $0.02 \mathrm{~g} / \mathrm{l}$. After adding the enzyme solution (iKnowzyme acid $2 X \mathrm{X}$ cellulase), the samples were collected at a specific time interval and the reaction was stopped by heating at $90^{\circ} \mathrm{C}$ for $10 \mathrm{~min}$ [26]. Then, the samples were diluted in distilled water and filtrated $(0.2 \mu \mathrm{m})$ prior to analysis for glucose and xylose by high performance liquid chromatography (HPLC).

\section{Acid hydrolysis}

Acid hydrolysis of $5 \mathrm{~g}$ APEFB at $120^{\circ} \mathrm{C}$ was carried out in a $250 \mathrm{ml}$ flask with $50 \mathrm{ml} 0.5 \%(\mathrm{w} / \mathrm{v})$ acid. The acid solution consisted of $0.5 \%(\mathrm{w} / \mathrm{v})$ of acetic acid, formic acid, orthophosphoric acid, hydrochloric acid, nitric acid or sulfuric acid. The samples were detected periods time in the variety of 0-90 min. The samples were separated by filtration method and the filtrate was analyzed for furfural, hydroxymethylfurfural (HMF), glucose and xylose by HPLC. The acid which gave the highest sugar production was selected for further study.

\section{Central composite design}

The hydrolysis of APEFB for sugar production by the enzyme and the selected acid, was optimized by the response surface methodology (RSM). Central composite design (CCD) was set to optimize the parameters for sugar production.

The experimental ranges and levels of independent process variables for the sugar produced from the APEFB are shown in Table 1. Two factors chosen for an enzymatic hydrolysis were enzyme dose and liquid to solid ratio. While two factors for an 
acid hydrolysis were acid concentration and hydrolysis temperature. The factors were examined at five different levels according to the equation (1):

$\mathrm{Y}_{\mathrm{i}}=\beta_{0}+\beta_{1} \mathrm{X}_{1}+\beta_{2} \mathrm{X}_{2}+\beta_{12} \mathrm{X}_{1} \mathrm{X}_{2}+\beta_{11} \mathrm{X}_{1}^{2}+\beta_{22} \mathrm{X}_{2}^{2}$

Where $Y_{i}$ was the predicted response (glucose or xylose); $X_{1}$ and $X_{2}$ were independent variables, $\beta_{0}$ was the regression coefficient at the center point; $\beta_{1}$ and $\beta_{2}$ were the linear coefficients; $\beta_{12}$ was the second order interaction coefficients and $\beta_{11}$ and $\beta_{22}$ were the quadratic coefficients. The created regression model was calculated by evaluating the values of regression coefficients, analysis of variance (ANOVA), $p$ - and $F$-values. The coefficient of determination, $\mathrm{R}^{2}$ was calculated for the value of fit of the polynomial template equivalence. The statistical software used to detect the investigational model as well as to create a regression model to expect the optimal combinations contemplating the outcomes of linear, quadratic and the interaction on total sugar concentration is the Design-Expert version 7.0.0 (Stat-Ease Inc. Minneapolis; free trial).

\section{Sugars, furfural, and HMF analysis}

Glucose and xylose concentrations were determined by HPLC (Agilent serie 1200, Agilent, USA) with Transgenomic ${ }^{\mathrm{TM}}$ CarboSep CH0682 column (7.8 x 300 mm, 7-micron, Teknokroma Anlítika, Spain) using RI detector. Water was used as the mobile phase; the running temperature was operated at $80^{\circ} \mathrm{C}$ and the flow rate was operated at $0.4 \mathrm{ml} / \mathrm{min}$ [27]. Standard glucose and xylose were run in the same condition. All the standard sugars and samples were filtered through $0.22 \mu \mathrm{m}$ nylon membrane prior to analysis. The furfural and HMF were determined by HPLC with LiChrospher ${ }^{\circledR} \mathrm{RP}-18(5 \mu \mathrm{m} ; 125 \times 4 \mathrm{~mm})$ column (Merck KGaA, 64271 Darmstadt, Germany) combined with UV $276 \mathrm{~nm}$ detector (Rezende et al. 2011). Water and acetonitrile in the ratio of $90: 10(\mathrm{v} / \mathrm{v})$ was used as the mobile phase with the temperature at $25^{\circ} \mathrm{C}$ and $1.0 \mathrm{ml} / \mathrm{min}$ of the flow rate. Standard furfural and HMF were run in the same condition.

\section{Results And Discussion}

\section{Enzymatic hydrolysis}

\section{Time course of an enzymatic hydrolysis}

The iKnowzyme acid $2 X \mathrm{~L}$ cellulase used in this study had cellulase activity of $16,000 \mathrm{U} \mathrm{ml}^{-1}$ and xylanase activity of $570 \mathrm{U} \mathrm{ml}$

${ }^{1}$ with a protein content of $278.5 \mathrm{mg} \mathrm{ml}^{-1}$. Time course of sugar production from the hydrolysis of APEFB by the iKnowzyme acid $2 \mathrm{XL}$ cellulase is shown in Fig. 1. The results show that glucose and xylose concentrations were slightly increased when increasing the hydrolysis time. The maximum glucose $(24.65 \mathrm{~g} / \mathrm{l})$ and xylose $(1.77 \mathrm{~g} / \mathrm{l})$ were obtained at $120 \mathrm{~h}$.

\section{Statistical modeling for an enzymatic hydrolysis}

The APEFB ( $5 \mathrm{~g}$ ) was hydrolyzed by adding to $45 \mathrm{ml} 50 \mathrm{mM}$ acetate buffer $\mathrm{pH} 5.0$ with Tween $800.3 \mathrm{~g} / \mathrm{l}$ and potassium metabisulfite $0.02 \mathrm{~g} / \mathrm{l}$. The enzyme dose and liquid to solid ratio were parameters used in this experiment. The conditions for hydrolysis were done at $150 \mathrm{rpm}$ at $50^{\circ} \mathrm{C}$ for $120 \mathrm{~h}$. The results found that the maximum glucose $(65.61 \mathrm{~g} / \mathrm{l})$ and xylose $(2.22$ $\mathrm{g} / \mathrm{l}$ ) concentrations were observed in the run number 7 and 3, respectively (Table 2). The quadratic models in terms of coded variables were shown in equation (2) and (3), where $Y_{1}$ represented glucose concentration and $Y_{2}$ represented $x y l o s e$ concentration as a function of the enzyme dose $\left(\mathrm{X}_{1}\right)$ and liquid to solid ratio $\left(\mathrm{X}_{2}\right)$.

$Y_{1}=19.85+2.90 X_{1}-2.09 X_{2}-0.06 X_{1} X_{2}-0.02 X_{1}^{2}+0.04 X_{2}^{2}$

$\mathrm{Y}_{2}=2.77-0.04 \mathrm{X}_{1}-0.06 \mathrm{X}_{2}+1.05 \mathrm{E}-003 \mathrm{X}_{1} \mathrm{X}_{2}+6.52 \mathrm{E}-004 \mathrm{X}_{1}{ }^{2}-1.89 \mathrm{E}-004 \mathrm{X}_{2}{ }^{2}$

The response function and experimental data of the regression analysis were performed and the second order model for all responses was evaluated by ANOVA (Table 3 and 4). The greater the $F$-value indicates that the factors explain adequately the variation in the data about its mean, and the estimated factor effects are real. The results showed that the value of the adjusted 
$\mathrm{R}^{2}$ determination for glucose and xylose productions was also very high ( $99.30 \%$ and $96.63 \%$, respectively) which indicated a high accuracy of the model [28].

Estimations of glucose and xylose concentrations over independent variables, enzyme dose $\left(X_{1}\right)$ and the liquid to solid ratio $\left(X_{2}\right)$ in terms of response surfaces are shown in Fig. 2. The maximum concentrations of glucose $(65.61 \mathrm{~g} / \mathrm{l})$ and $x y l o s e(2.13 \mathrm{~g} / \mathrm{l})$ were observed by using the enzyme dose and liquid to solid ratio of $40 \mathrm{U} / \mathrm{g}$ APEFB and $10 \mathrm{ml}$ of liquid per $\mathrm{g}$ of APEFB (100 g/l), respectively for $120 \mathrm{~h}$. Shamsudin et al. [29] report that glucose and xylose concentration of 8.75 and $3.75 \mathrm{~g} / \mathrm{l}$ were obtained after hydrolysis the steam pretreated EFB $(50 \mathrm{~g} / \mathrm{l})$ with Celuclast $1.5 \mathrm{~L}(25 \mathrm{U} / \mathrm{g} \mathrm{EFB})$ at $50^{\circ} \mathrm{C}$ for $24 \mathrm{~h}$. In another study, glucose concentration $(17.5 \mathrm{~g} / \mathrm{l})$ was obtained after hydrolysis the water pretreated EFB $(25 \mathrm{~g} / \mathrm{l})$ with $70 \mathrm{U} / \mathrm{g} \mathrm{EFB}$ at $50^{\circ} \mathrm{C}$ for $48 \mathrm{~h}[30]$.

To confirm the results, the hydrolysis of APEFB by the enzyme was carried out in triplicate under the most and least optimized conditions. The results are shown in Table 5 . The highest glucose and xylose concentrations obtained were $65.71 \mathrm{~g} / \mathrm{l}(0.66 \mathrm{~g} / \mathrm{g}$ APEFB) and $2.14 \mathrm{~g} / \mathrm{l}(0.02 \mathrm{~g} / \mathrm{g}$ APEFB), respectively when hydrolysis using the iKnowzyme acid $2 X L$ cellulase $40 \mathrm{U} / \mathrm{g}$ APEFB and the liquid to solid ratio of $10 \mathrm{ml} / \mathrm{g}$ APEFB $\left(100 \mathrm{~g} / \mathrm{l}\right.$ APEFB) with shaking at $150 \mathrm{rpm}$ and $50^{\circ} \mathrm{C}$ for $120 \mathrm{~h}$. It was found that the sugars concentrations obtained from enzymatic hydrolysis of APEFB of the experimental tests were similar to the sugar concentrations in the prediction models.

\section{Acid hydrolysis}

\section{Effect of type of acids}

The effect of various acids on the hydrolysis of APEFB to produce glucose and xylose was done by using $0.5 \%$ (w/v) of acid solutions at $120^{\circ} \mathrm{C}$. The results are shown in Fig 3. Glucose, xylose, furfural and HMF concentrations were increased when increasing the time for hydrolysis. The highest glucose concentration $(4.93 \mathrm{~g} / \mathrm{l})$ and xylose concentration $(15.12 \mathrm{~g} / \mathrm{l})$ were obtained when hydrochloric acid was used for hydrolysis. The highest furfural concentration was obtained after hydrolysis the APEFB with nitric acid $(1.65 \mathrm{~g} / \mathrm{l})$, while the highest HMF was obtained with sulfuric acid $(0.41 \mathrm{~g} / \mathrm{l})$. The results show that the hydrolysis of APEFB with acid gave xylose concentration higher than glucose. Chong et al. [7] found that the highest yield of glucose $(2.75 \mathrm{~g} / \mathrm{l})$ and xylose $(24.14 \mathrm{~g} / \mathrm{l})$ was obtained after hydrolysis the EFB with $6 \%$ sulfuric acid at $120^{\circ} \mathrm{C}$ for 15 min. Rahman et al. [31] report that the maximum xylose, glucose and furfural concentrations of $29.4,2.34$ and $0.8 \mathrm{~g} / \mathrm{l}$ were observed after hydrolysis the EFB by using $6 \%$ sulfuric acid at $120^{\circ} \mathrm{C}$ for $15 \mathrm{~min}$. The ultrasonic pretreated EFB hydrolysis using $2 \%$ sulfuric acid at $100^{\circ} \mathrm{C}$ for 45 min provied glucose and xylose of 2.0 and $23.2 \mathrm{~g} / \mathrm{l}$, respectively [32].

\section{Statistical modeling for acid hydrolysis}

Since hydrolysis of APEFB by $\mathrm{HCl}$ provided highest sugar productions and less furfural and HMF, it was futher used to optimize the sugar productions. The experimental ranges and levels of the independent process variables including the $\mathrm{HCl}$ concentration and temperature for hydrolysis of APEFB are shown in Table 5. The design of the acid hydrolysis experiments including dependent variables, $Y_{3}$ (glucose), $Y_{4}$ (xylose), $Y_{5}$ (furfural) and $Y_{6}$ (HMF) are also given in Table 6. The release of glucose and xylose in the hydrolysate after acid hydrolysis was dependent on experimental operating conditions. The maximum concentrations of glucose and xylose obtained were 10.75 and $15.86 \mathrm{~g} / \mathrm{l}$, respectively when the $\mathrm{HCl}$ concentration, temperature and reaction time were $6 \%(\mathrm{w} / \mathrm{v})$ at $110^{\circ} \mathrm{C}$ and $90 \mathrm{~min}$, respectively. The lowest furfural and HMF concentrations $(1.41$ and 0.51 $\mathrm{g} / \mathrm{l})$ occurred when the reaction was carried out with $6 \% \mathrm{HCl}$ at $96^{\circ} \mathrm{C}$ for $90 \mathrm{~min}$.

The quadratic models in terms of coded variables are shown in equation (4) - (7), as a function of reaction acid ( $\mathrm{HCl})$ concentration $\left(\mathrm{X}_{3}\right)$ and temperature $\left(\mathrm{X}_{4}\right)$.

$Y_{3}=-223.31+17.11 X_{3}+3.24 X_{4}-0.09 X_{3} X_{4}-0.57 X_{3}^{2}-0.01 X_{4}^{2}$

$Y_{4}=-300.42+16.72 X_{3}+4.70 X_{4}-0.11 X_{3} X_{4}-0.45 X_{3}{ }^{2}-0.02 X_{4}^{2}$

$Y_{5}=10.87-3.33 X_{3}-0.047 X_{4}+0.02 X_{3} X_{4}+0.15 X_{3}{ }^{2}-3.08 E-005 X_{4}{ }^{2}$ 
$Y_{6}=-15.13+0.74 X_{3}+0.24 X_{4}-8.99 E-04 X_{3} X_{4}-0.005 X_{3}^{2}-1.03 E-003 X_{4}^{2}$

To fit the response function and experimental data, regression analysis was performed and the second order model for all response was evaluated by ANOVA. The resules are presented in Table 7-10. In this experiment, the value of $R^{2}$ of glucose, xylose, furfural, and HMF production from APEFB were 93.97, 95.52, 96.85, and 94.16\%, respectively. These values indicate a high degree of correlation between the experimental and the predicted values. The results show that the values of the adjusted $\mathrm{R}^{2}$ determination were also very high $(87.94 \%, 91.03 \%, 93.71 \%$ and $88.32 \%$ for glucose, xylose, furfural and HMF productions, respectively) which indicate a high accuracy of the model [28].

Estimations of sugar concentration (glucose and xylose) and by-products (furfural and HMF) from the hydrolysis of APEFB over independent variables (acid concentration $\left(X_{3}\right)$ and temperature $\left(X_{4}\right)$ ) in term of response surfaces are shown in Fig. 4 and 5.

The maximum concentration of glucose $(10.56 \mathrm{~g} / \mathrm{l})$ was obtained by conducting hydrolysis experiment with $5.85 \% \mathrm{HCl}$ at $114^{\circ} \mathrm{C}$ for 90 min while the maximum concentrations of xylose $(15.86 \mathrm{~g} / \mathrm{l})$ was obtained by hydrolysis with $4 \% \mathrm{HCl}$ at $120^{\circ} \mathrm{C}$ for 90 min. On the other hand, maximum concentration of furfural $(3.68 \mathrm{~g} / \mathrm{l})$ and HMF $(0.69 \mathrm{~g} / \mathrm{l})$ was obtained by hydrolysis with $7.32 \% \mathrm{HCl}$ at $120^{\circ} \mathrm{C}$ for 90 min but the minimum concentration of furfural $(1.92 \mathrm{~g} / \mathrm{l})$ and $\mathrm{HMF}(0.38 \mathrm{~g} / \mathrm{l})$ was obtained by hydrolysis with $4 \% \mathrm{HCl}$ and at $100^{\circ} \mathrm{C}$ for $90 \mathrm{~min}$. Thamsee et al. [33] reported that the maximum glucose and xylose concentrations of 1.80 and $33.16 \mathrm{~g} / \mathrm{l}$ was obtained when hydrolysis the EFB with $4.0 \%$ sulfuric acid at $119^{\circ} \mathrm{C}$ for $60 \mathrm{~min}$. While the maximum glucose and xylose concentrations ( 1.2 and $11.3 \mathrm{~g} / \mathrm{l}$, respectively) were obtained by using a combined of $0.5 \%$ sulfuric acid and $0.2 \%$ phosphoric acid at $160^{\circ} \mathrm{C}$ for $10 \mathrm{~min}$ [34].

Based on the models, the numerical optimization was carried out with considering each value of response in four conditions. The results are shown in Table 11. The best results of glucose and xylose concentrations obtained by the experiment were 10.70 $\mathrm{g} / \mathrm{l}\left(0.11 \mathrm{~g} / \mathrm{g}\right.$ APEFB) and $15.30 \mathrm{~g} / \mathrm{l}\left(0.15 \mathrm{~g} / \mathrm{g}\right.$ APEFB), respectively after hydrolysis of the APEFB with $5.80 \% \mathrm{HCl}$ at $114^{\circ} \mathrm{C}$ for 90 min. The highest concentrations of furfural $(3.81 \mathrm{~g} / \mathrm{l})$ and $\mathrm{HMF}(0.74 \mathrm{~g} / \mathrm{l})$ were obtained after hydrolysis with $7.32 \% \mathrm{HCl}$ at $120^{\circ} \mathrm{C}$. Most diluted acid and high temperature was found to generate by-products such as furfural and HMF [31]. Furfural and HMF presented in the hydrolysate higher than $0.2 \mathrm{~g} / \mathrm{l}$ were potential inhibitors to microbial metabolism. They inhibited the fermentation process by causing cell morphological change or ultimate death of the microorganism [35]. To keep the concentration of furfural and HMF in the hydrolysate at a low level it is necessary to run the hydrolysis reaction at less severe conditions.

\section{Conclusion}

EFB from palm oil mill can be used for glucose and xylose productions either by an enzymatic hydrolysis or an acid hydrolysis. The APEFB hydrolysis with iKnowzyme acid 2XL cellulase provided glucose and xylose concentrations 6 time higher than hydrolysis by using $\mathrm{HCl}$. The enzymatic hydrolysis of APEFB using iKnowzyme acid $2 X \mathrm{~L}$ cellulase has a number of advantages over the acid hydrolysis. The enzymatic hydrolysis is a very promising method for saccharification of APEFB. The hydrolysis is performed under mild conditions. The glucose obtained from enzymatic hydrolysis was higher than using acid hydrolysis. However, the xylose concentration obtained from acid hydrolysis was higher than using an enzymatic hydrolysis. In addition, the using of acid was harmful to the environment and gave by-products such as furfural and HMF. This experiment showed that EFB can be used as a potential source for glucose and xylose productions which could be fuether used for the biorefinery process to produce biofuel and value chemicals.

\section{Declarations}

\section{Acknowledgments}

This study was funded by Strategic Scholarships of Frontier Research Network (Specific for the Southern region), the Office of the Higher Education Commission (Grant no. 022/2012), National Research Council of Thailand (Grant year 2014:

157838/2557RPCS52577), and the Graduate School of Prince of Songkla University. 
Compliance with Ethical Standards Funding: This study was funded by Strategic Scholarships of Frontier Research Network (Specific for the Southern region), the Office of the Higher Education Commission (Grant no. 022/2012), National Research Council of Thailand (Grant year Grant year 2014: 157838/2557RPCS52577), and the Graduate School of Prince of Songkla University.

Conflict of Interest: The authors declare that they have no conflict of interest.

Ethical approval: This article does not contain any studies with human participants or animals performed by any of the authors.

Informed consent: Informed consent was obtained from all individual participants of this study.

Data availability: All data generated or analyzed during in this study are included in this published article and its supplementary information files.

\section{References}

1. Kucharska, K., Rybarczyk, P., Hołowacz, I., Łukajtis, R., Glinka, M., \& Kamiński, M. (2018). Pretreatment of lignocellulosic materials as substrates for fermentation processes. Molecules, 23(11), 2937. https://doi.org/10.3390/molecules23112937

2. Den, W., Sharma, V. K., Lee, M., Nadadur, G., \& Varma, R. S. (2018). Lignocellulosic biomass transformations via greener oxidative pretreatment processes: Access to energy and value-added chemicals. Frontiers in Chemistry, 6(141), 1-23

3. Irmak, S. (2017). Biomass as raw material for production of high-value products. Jaya Shankar Tumuluru, IntechOpen, Biomass Volume Estimation and Valorization for Energy. https://doi.org/10.5772/65507

4. Kanchanasuta, S., \& Pisutpaisal, N. (2016). Waste utilization of palm oil decanter cake on biogas fermentation. International Journal of Hydrogen Energy, 41(35), 15661-15666

5. Khatun, R., Reza, M. I. H., Moniruzzaman, M., \& Yaakob, Z. (2017). Sustainable oil palm industry: The possibilities. Renewable and Sustainable Energy Reviews, 76, 608-619

6. Prasertsan, S., \& Prasertsan, P. (1996). Biomass residues from palm oil mills in Thailand: An overview on quantity and potential usage. Biomass and Bioenergy, 11(5), 387-395

7. Chong, P. S., Jahim, J. M., Harun, S., Lim, S. S., Mutalib, S. A., Hassan, O., \& Nor, M. T. M. (2013). Enhancement of batch biohydrogen production from prehydrolysate of acid treated oil palm empty fruit bunch. International Journal of Hydrogen Energy, 38(22), 9592-9599

8. Hamzah, F., Idris, A., \& Shuan, T. K. (2011). Preliminary study on enzymatic hydrolysis of treated oil palm (Elaeis) empty fruit bunches fibre (EFB) by using combination of cellulase and $\beta$ 1-4 glucosidase. Biomass and Bioenergy, 35(3), 1055-1059

9. Sinjaroonsak, S., Chaiyaso, T., \& H-Kittikun, A. (2019). Optimization of cellulase and xylanase productions by Streptomyces thermocoprophilus strain TC13W using oil palm empty fruit bunch and tuna condensate as substrates. Applied Biochemistry and Biotechnology, 189(1), 76-86

10. Sinjaroonsak, S., Chaiyaso, T., \& H-Kittikun, A. (2020). Optimization of cellulase and xylanase productions by Streptomyces thermocoprophilus TC13W using low cost pretreated oil palm empty fruit bunchv. Waste and Biomass Valorization, 11(8), 3925-3936

11. Saswattecha, K., Romero, M. C., Hein, L., Jawjit, W., \& Kroeze, C. (2015). Non-CO2 greenhouse gas emissions from palm oil production in Thailand. Journal of Integrative Environmental Sciences, 12(sup1), 67-85

12. Saswattecha, K., Kroeze, C., Jawjit, W., \& Hein, L. (2017). Improving environmental sustainability of Thai palm oil production in 2050. Journal of Cleaner Production, 147, 572-588

13. Chiew, Y. L., \& Shimada, S. (2013). Current state and environmental impact assessment for utilizing oil palm empty fruit bunches for fuel, fiber and fertilizer - A case study of Malaysia. Biomass and Bioenergy, 51, 109-124

14. Patthanaissaranukool, W., Polprasert, C., \& Englande, A. J. (2013). Potential reduction of carbon emissions from crude palm oil production based on energy and carbon balances. Applied Energy, 102, 710-717 
15. Saswattecha, K., Kroeze, C., Jawjit, W., \& Hein, L. (2016). Options to reduce environmental impacts of palm oil production in Thailand. Journal of Cleaner Production, 137, 370-393

16. Aditiawati, P., Dungani, R., \& Amelia, C. (2018). Enzymatic production of cellulose nanofibers from oil palm empty fruit bunch (EFB) with crude cellulase of Trichoderma sp. Materials Research Express, 5(3), 1-8

17. Anita, S. H., Fitria, Solihat, N. N., Sari, F. P., Risanto, L., Fatriasari, W., \& Hermiati, E. (2019). Optimization of microwaveassisted oxalic acid pretreatment of oil palm empty fruit bunch for production of fermentable sugars. Waste and Biomass Valorization,1-15.

18. Chang, S. H. (2014). An overview of empty fruit bunch from oil palm as feedstock for bio-oil production. Biomass and Bioenergy, 62, 174-181

19. Osman, N. B., Shamsuddin, N., \& Uemura, Y. (2016). Activated carbon of oil palm empty fruit bunch (EFB); Core and shaggy. Procedia Engineering, 148, 758-764

20. Palamae, S., Dechatiwongse, P., Choorit, W., Chisti, Y., \& Prasertsan, P. (2017). Cellulose and hemicellulose recovery from oil palm empty fruit bunch (EFB) fibers and production of sugars from the fibers. Carbohydrate Polymers, 155, 491-497

21. Sembiring, K. C., Rinaldi, N., \& Simanungkalit, S. P. (2015). Bio-oil from fast pyrolysis of empty fruit bunch at various temperature. Energy Procedia, 65, 162-169

22. Siddiquee, S., Shafawati, S. N., \& Naher, L. (2017). Effective composting of empty fruit bunches using potential Trichoderma strains. Biotechnology Reports, 13, 1-7

23. Tang, P. L., Abdul, P. M., Engliman, N. S., \& Hassan, O. (2018). Effects of pretreatment and enzyme cocktail composition on the sugars production from oil palm empty fruit bunch fiber (OPEFBF). Cellulose, 25(8), 4677-4694

24. Miller, G. L. (1959). Use of dinitrosalicylic acid reagent for determination of reducing sugar. Analytical Chemistry, 31(3), 426-428

25. Lowry, O. H., Rosebrough, N. J., Farr, A. L., \& Randall, R. J. (1951). Protein measurement with the Folin phenol reagent. The Journal of Biological Chemistry, 193(1), 265-275

26. Yeh, A. I., Huang, Y. C., \& Chen, S. H. (2010). Effect of particle size on the rate of enzymatic hydrolysis of cellulose. Carbohydrate Polymers, 79(1), 192-199

27. Alvira, P., Tomás-Pejó, E., Negro, M. J., \& Ballesteros, M. (2011). Strategies of xylanase supplementation for an efficient saccharification and cofermentation process from pretreated wheat straw. Biotechnology Progress, 27(4), 944-950

28. Box, G. E. P., \& Wilson, K. B. (1951). On the experimental attainment of optimum conditions. Journal of the Royal Statistical Society. Series $B$ (Methodological), 13(1), 1-45

29. Shamsudin, S., Md Shah, U. K., Zainudin, H., Abd-Aziz, S., Mustapa Kamal, S. M., Shirai, Y., \& Hassan, M. A. (2012). Effect of steam pretreatment on oil palm empty fruit bunch for the production of sugars. Biomass and Bioenergy, 36, 280-288

30. Ying, T. Y., Teong, L. K., Abdullah, W. N. W., \& Peng, L. C. (2014). The effect of various pretreatment methods on oil palm empty fruit bunch (EFB) and kenaf core fibers for sugar production. Procedia Environmental Sciences, 20, 328-335

31. Rahman, S. H. A., Choudhury, J. P., Ahmad, A. L., \& Kamaruddin, A. H. (2007). Optimization studies on acid hydrolysis of oil palm empty fruit bunch fiber for production of xylose. Bioresource Technology, 98(3), 554-559

32. Yunus, R., Salleh, S. F., Abdullah, N., \& Biak, D. R. A. (2010). Effect of ultrasonic pre-treatment on low temperature acid hydrolysis of oil palm empty fruit bunch. Bioresource Technology, 101(24), 9792-9796

33. Thamsee, T., Cheirsilp, B., Yamsaengsung, R., Ruengpeerakul, T., Choojit, S., \& Sangwichien, C. (2018). Efficient of acid hydrolysis of oil palm empty fruit bunch residues for xylose and highly digestible cellulose pulp productions. Waste and Biomass Valorization, 9(11), 2041-2051

34. Zhang, D., Ong, Y. L., Li, Z., \& Wu, J. C. (2012). Optimization of dilute acid-catalyzed hydrolysis of oil palm empty fruit bunch for high yield production of xylose. Chemical Engineering Journal, 181-182, 636-642

35. Casey, E., Sedlak, M., Ho, N. W. Y., \& Mosier, N. S. (2010). Effect of acetic acid and pH on the cofermentation of glucose and xylose to ethanol by a genetically engineered strain of Saccharomyces cerevisiae. FEMS Yeast Research, 10(4), 385-393 


\section{Tables}

Table 1 Experimental ranges and levels of independent process variables for the hydrolysis of alkaline peroxide pretreated oil palm empty fruit bunch (APEFB) by iKnowzyme acid 2XL cellulase and hydrochloric acid

\begin{tabular}{|lllllll|}
\hline Independent variable & Symbol & \multicolumn{2}{l}{ Levels } & & & \\
\cline { 5 - 8 } & & $-\mathrm{a}$ & -1 & 0 & +1 & $+\mathrm{a}$ \\
\hline Enzymatic hydrolysis & & & & & & \\
\hline Enzyme dose (U/g APEFB) & $\mathrm{X}_{1}$ & 15.86 & 20 & 30 & 40 & 44.14 \\
\hline Liquid:solid (ml/g APEFB) & $\mathrm{X}_{2}$ & 6.59 & 10 & 15 & 20 & 23.41 \\
\hline$\underline{\text { Acidic hydrolysis }}$ & & & & & & \\
\hline Acid concentration (\% w/v) & $\mathrm{X}_{3}$ & 3.17 & 4 & 6 & 8 & 8.83 \\
\hline Temperature $\left({ }^{\circ} \mathrm{C}\right)$ & $\mathrm{X}_{4}$ & 96 & 100 & 110 & 120 & 124 \\
\hline
\end{tabular}

Table 2 The arrangement of CCD for enzyme concentration and liquid to alkaline peroxide pretreated oil palm empty fruit bunch ratio used in RSM study for glucose and xylose productions

\begin{tabular}{|c|c|c|c|c|}
\hline \multirow[t]{3}{*}{ Run } & \multirow{3}{*}{$\begin{array}{l}\text { Variable level } \\
\text { Enzyme* dose; } \\
\text { U/g APEFB }\left(x_{1}\right)\end{array}$} & \multicolumn{3}{|c|}{ Response parameter $\mathbf{g} / \mathrm{l}$} \\
\hline & & Liquid: solid; $\mathrm{ml} / \mathrm{g}\left(\mathrm{x}_{2}\right)$ & Glucose & Xylose \\
\hline & & & $\left(Y_{1}\right)$ & $\left(Y_{2}\right)$ \\
\hline 1 & $30.00(0)$ & $15.00(0)$ & 41.50 & 1.84 \\
\hline 2 & $15.86(-a)$ & $15.00(0)$ & 25.00 & 1.75 \\
\hline 3 & $44.14(+a)$ & $15.00(0)$ & 52.24 & 2.22 \\
\hline 4 & $30.00(0)$ & $7.93(-a)$ & 62.95 & 2.05 \\
\hline 5 & $40.00(+1)$ & $20.00(+1)$ & 33.16 & 1.93 \\
\hline 6 & $30.00(0)$ & $22.07(+a)$ & 25.67 & 1.64 \\
\hline 7 & $40.00(+1)$ & $10.00(-1)$ & 65.61 & 2.13 \\
\hline 8 & $20.00(-1)$ & $10.00(-1)$ & 41.93 & 1.88 \\
\hline 9 & $30.00(0)$ & $15.00(0)$ & 40.37 & 1.81 \\
\hline 10 & $20.00(-1)$ & $20.00(+1)$ & 21.58 & 1.48 \\
\hline 11 & $30.00(+1)$ & $15.00(0)$ & 43.37 & 1.82 \\
\hline
\end{tabular}

* iKnowzyme acid $2 X L$ cellulase

The number inside bracket is coded value and the number outside bracket is actual value

Table 3 Analysis of variance (ANOVA) for glucose production from alkaline peroxide pretreated oil palm empty fruit bunch by iKnowzyme acid $2 X L$ cellulase 


\begin{tabular}{|llllll|}
\hline Source & SS & DF & MS & F-value & $p$-value \\
\hline Model & 2142.69 & 5 & 428.54 & 285.33 & $<0.0001$ \\
\hline Residual & 7.51 & 5 & 1.50 & & \\
\hline Lack of fit & 2.92 & 3 & 0.97 & 0.42 & 0.7577 \\
\hline Pure error & 4.59 & 2 & 2.30 & & \\
\hline Total & 2150.20 & 10 & & & \\
$\mathrm{R}^{2}$ & 0.9965 & & & Adjust $\mathrm{R}^{2}=0.9930$ \\
\hline
\end{tabular}

SS $=$ Sum of squares, $\mathrm{DF}=$ Degree of freedom, $\mathrm{MS}=$ Mean squares

Table 4 Analysis of variance (ANOVA) for xylose production from alkaline peroxide pretreated oil palm empty fruit bunch by iKnowzyme acid $2 X L$ cellulase

\begin{tabular}{|llllll|}
\hline Source & SS & DF & MS & F-value & $p$-value \\
\hline Model & 0.44 & 5 & 0.089 & 58.41 & 0.0002 \\
\hline Residual & $7.58 \mathrm{E}-003$ & 5 & $1.52 \mathrm{E}-003$ & & \\
\hline Lack of fit & $7.16 \mathrm{E}-003$ & 3 & $2.39 \mathrm{E}-003$ & 11.17 & 0.0833 \\
\hline Pure error & $4.27 \mathrm{E}-004$ & 2 & $2.14 \mathrm{E}-004$ & & \\
\hline Total & 0.45 & 10 & & & \\
$\mathrm{R}^{2}$ & 0.9832 & & & Adjust $\mathrm{R}^{2}=0.9663$ \\
\hline
\end{tabular}

$\mathrm{SS}=$ Sum of squares, $\mathrm{DF}=$ Degree of freedom, MS = Mean squares

Table 5 The validation of the developed quadratic model and optimum parameter point for glucose and xylose production from alkaline peroxide pretreated oil palm empty fruit bunch by iKnowzyme acid 2XL cellulase at various conditions

\begin{tabular}{|c|c|c|c|c|c|c|}
\hline \multirow[t]{3}{*}{ Conditions } & \multirow[t]{3}{*}{ Enzyme dose (U/g APEFB) } & \multirow[t]{3}{*}{ Liquid: solid ratio (ml/g) } & \multicolumn{4}{|c|}{ Concentration (g/l) } \\
\hline & & & \multicolumn{2}{|c|}{ Predicted } & \multicolumn{2}{|l|}{ Experiment } \\
\hline & & & Glu & Xyl & Glu & Xyl \\
\hline 1 & 40.00 & 10.00 & 66.46 & 2.15 & $65.71(-1.1 \%)$ & $2.14(-0.5 \%)$ \\
\hline 2 & 21.75 & 18.09 & 26.71 & 1.61 & $21.78(-18.5 \%)$ & $1.62(+0.6 \%)$ \\
\hline 3 & 37.37 & 15.75 & 25.66 & 1.61 & $30.12(+17.4 \%)$ & $1.81(+12.4 \%)$ \\
\hline 4 & 39.51 & 10.00 & 65.98 & 2.14 & $65.62(-0.6 \%)$ & $2.15(+0.5 \%)$ \\
\hline
\end{tabular}

Where; Glu = glucose, $\mathrm{Xyl}=$ xylose

Data in the parenthesis showing \% error obtained

Bold values indicate the selected optimum condition solutions for desired results

Table 6 Effect of $\mathrm{HCl}$ concentration and temperature on the hydrolysis of alkaline peroxide pretreated empty fruit bunch 


\begin{tabular}{|lllllll|}
\hline Run & Variable level & & \multicolumn{3}{l}{ Response parameter $\mathbf{g} / \mathbf{l}$} \\
& Acid concentration; $\%(w / v)\left(\mathbf{x}_{3}\right)$ & Temperature; ${ }^{\circ} \mathrm{C}\left(\mathbf{x}_{4}\right)$ & Glucose & Xylose & Furfural & HMF \\
& & & $\left(Y_{3}\right)$ & $\left(Y_{4}\right)$ & $\left(Y_{5}\right)$ & $\left(Y_{6}\right)$ \\
\hline 1 & $6(0)$ & $110(0)$ & 10.50 & 15.18 & 2.39 & 0.81 \\
\hline 2 & $6(0)$ & $96(-a)$ & 7.45 & 10.46 & 1.41 & 0.51 \\
\hline 3 & $6(0)$ & $124(+a)$ & 9.03 & 14.44 & 2.86 & 0.66 \\
\hline 4 & $6(0)$ & $110(0)$ & 10.75 & 15.26 & 2.34 & 0.83 \\
\hline 5 & $4(-1)$ & $120(+1)$ & 8.58 & 15.43 & 2.23 & 0.62 \\
\hline 6 & $6(0)$ & $110(0)$ & 10.10 & 15.86 & 1.95 & 0.77 \\
\hline 7 & $8(+1)$ & $120(+1)$ & 6.61 & 10.15 & 4.61 & 0.64 \\
\hline 8 & $3.17(-a)$ & $110(0)$ & 6.45 & 13.49 & 2.47 & 0.41 \\
\hline 9 & $4(-1)$ & $100(-1)$ & 3.32 & 8.16 & 1.88 & 0.33 \\
\hline 10 & $8(+1)$ & $100(-1)$ & 8.68 & 11.33 & 2.85 & 0.43 \\
\hline 11 & $8.83(+a)$ & $110(0)$ & 5.63 & 11.33 & 4.15 & 0.32 \\
\hline
\end{tabular}

The number inside bracket is coded value and the number outside bracket is actual value

Table 7 Analysis of variance (ANOVA) for glucose production from the hydrolysis of alkaline peroxide pretreated empty fruit bunch by hydrochloric acid

\begin{tabular}{|llllll|}
\hline Source & SS & DF & MS & F-value & $p$-value \\
\hline Model & 49.08 & 5 & 9.82 & 15.58 & 0.0045 \\
\hline Residual & 3.15 & 5 & 0.63 & & \\
Lack of fit & 2.93 & 3 & 0.98 & 9.05 & 0.1011 \\
\hline Pure error & 0.22 & 2 & 0.11 & & \\
\hline Total & 52.23 & 10 & & & \\
$\mathrm{R}^{2}$ & 0.9397 & & & Adjust $\mathrm{R}^{2}=0.8794$ \\
\hline
\end{tabular}

SS = Sum of squares, DF = Degree of freedom, MS = Mean squares

Table 8 Analysis of variance (ANOVA) for xylose production from the hydrolysis of alkaline peroxide pretreated empty fruit bunch by hydrochloric acid

\begin{tabular}{|llllll|}
\hline Source & SS & DF & MS & F-value & p-value \\
\hline Model & 66.45 & 5 & 13.29 & 21.31 & 0.0022 \\
\hline Residual & 3.12 & 5 & 0.62 & & \\
\hline Lack of fit & 2.84 & 3 & 0.95 & 6.79 & 0.1310 \\
\hline Pure error & 0.28 & 2 & 0.14 & & \\
\hline Total & 69.57 & 10 & & & \\
$\mathrm{R}^{2}$ & 0.9552 & & & Adjust $\mathrm{R}^{2}=0.9103$ \\
\hline
\end{tabular}

Page $11 / 16$ 
$S S=$ Sum of squares, $D F=$ Degree of freedom, MS = Mean squares

Table 9 Analysis of variance (ANOVA) for furfural production from the hydrolysis of alkaline peroxide pretreated empty fruit bunch by hydrochloric acid

\begin{tabular}{|llllll|}
\hline Source & SS & DF & MS & F-value & p-value \\
\hline Model & 8.88 & 5 & 1.78 & 30.78 & 0.0009 \\
\hline Residual & 0.29 & 5 & 0.058 & & \\
\hline Lack of fit & 0.18 & 3 & 0.057 & 1.03 & 0.5263 \\
\hline Pure error & 0.11 & 2 & 30.78 & & \\
\hline Total & 9.17 & 10 & & & \\
$\mathrm{R}^{2}$ & 0.9685 & & & Adjust $\mathrm{R}^{2}=0.9371$ \\
\hline
\end{tabular}

$\mathrm{SS}=$ Sum of squares, $\mathrm{DF}=$ Degree of freedom, MS = Mean squares

Table 10 Analysis of variance (ANOVA) for HMF production from the hydrolysis of alkaline peroxide pretreated empty fruit bunches by hydrochloric acid

\begin{tabular}{|llllll|}
\hline Source & SS & DF & MS & F-value & p-value \\
\hline Model & 0.33 & 5 & 0.066 & 16.12 & 0.0042 \\
\hline Residual & 0.021 & 5 & 0.004 & & \\
\hline Lack of fit & 0.018 & 3 & 0.006 & 5.72 & 0.1523 \\
\hline Pure error & 0.002 & 2 & 0.001 & & \\
\hline Total & 0.35 & 10 & & & \\
$\mathrm{R}^{2}$ & 0.9416 & & & Adjust $\mathrm{R}^{2}=0.8832$ \\
\hline
\end{tabular}

$\mathrm{SS}=$ Sum of squares, $\mathrm{DF}=$ Degree of freedom, MS = Mean squares

TABLE 11 Effect of acid concentration and temperature on the hydrolysis of alkaline peroxide pretreated empty fruit bunch for $90 \mathrm{~min}$

\begin{tabular}{|c|c|c|c|c|c|c|c|c|c|c|}
\hline \multirow[t]{3}{*}{ Conditions } & \multirow{3}{*}{$\begin{array}{l}\mathrm{HCl} \\
\text { concentration } \\
(\% \mathrm{w} / \mathrm{v})\end{array}$} & \multirow{3}{*}{$\begin{array}{l}\text { Temperature } \\
\left({ }^{\circ} \mathrm{C}\right)\end{array}$} & \multicolumn{8}{|c|}{ Concentration $(\mathrm{g} / \mathrm{l})$} \\
\hline & & & \multicolumn{4}{|c|}{ Predicted } & \multicolumn{4}{|c|}{ Experiment } \\
\hline & & & Glu & Xyl & FF & HMF & Glu & Xyl & $\mathrm{FF}$ & HMF \\
\hline 1 & 5.85 & 114 & 10.55 & 15.86 & 2.34 & 0.82 & $\begin{array}{l}10.70 \\
(+1.4 \%)\end{array}$ & $\begin{array}{l}15.30 \\
(-3.5 \%)\end{array}$ & 2.34 & $\begin{array}{l}0.67 \\
(-18.3 \%)\end{array}$ \\
\hline 2 & 4.22 & 115 & 9.22 & 15.72 & 2.15 & 0.66 & $\begin{array}{l}9.11 \\
(-1.2 \%)\end{array}$ & $\begin{array}{l}15.53 \\
(-1.2 \%)\end{array}$ & $\begin{array}{l}2.23 \\
(+3.7 \%)\end{array}$ & $\begin{array}{l}0.63 \\
(-4.5 \%)\end{array}$ \\
\hline 3 & 4.00 & 100 & 4.17 & 8.92 & 1.92 & 0.38 & $\begin{array}{l}3.22 \\
(-22.8 \%)\end{array}$ & $\begin{array}{l}8.07 \\
(-9.5 \%)\end{array}$ & $\begin{array}{l}1.86 \\
(-3.1 \%)\end{array}$ & $\begin{array}{l}0.30 \\
(-21.1 \%)\end{array}$ \\
\hline 4 & 7.32 & 120 & 8.00 & 12.61 & 3.68 & 0.69 & $\begin{array}{l}7.55 \\
(-5.6 \%)\end{array}$ & $\begin{array}{l}11.15 \\
(-11.6 \%)\end{array}$ & $\begin{array}{l}3.81 \\
(+3.5 \%)\end{array}$ & $\begin{array}{l}0.74 \\
(+7.2 \%)\end{array}$ \\
\hline
\end{tabular}

Where; Glu = glucose, $\mathrm{Xyl}=$ xylose, $\mathrm{FF}=$ furfural and HMF = hydroxymethylfurfural 


\section{Figures}

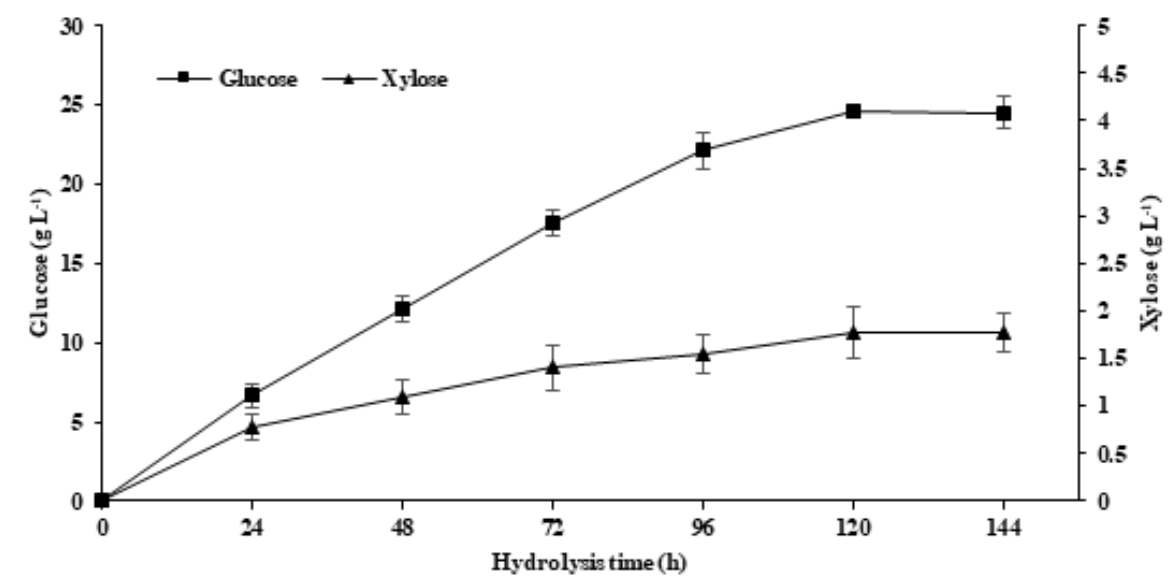

\section{Figure 1}

Time cause of glucose and xylose productions from alkaline peroxide pretreated empty fruit bunch using iKnowzyme acid $2 X \mathrm{~L}$ cellulase with shaking at $150 \mathrm{rpm}$ and $50^{\circ} \mathrm{C}$
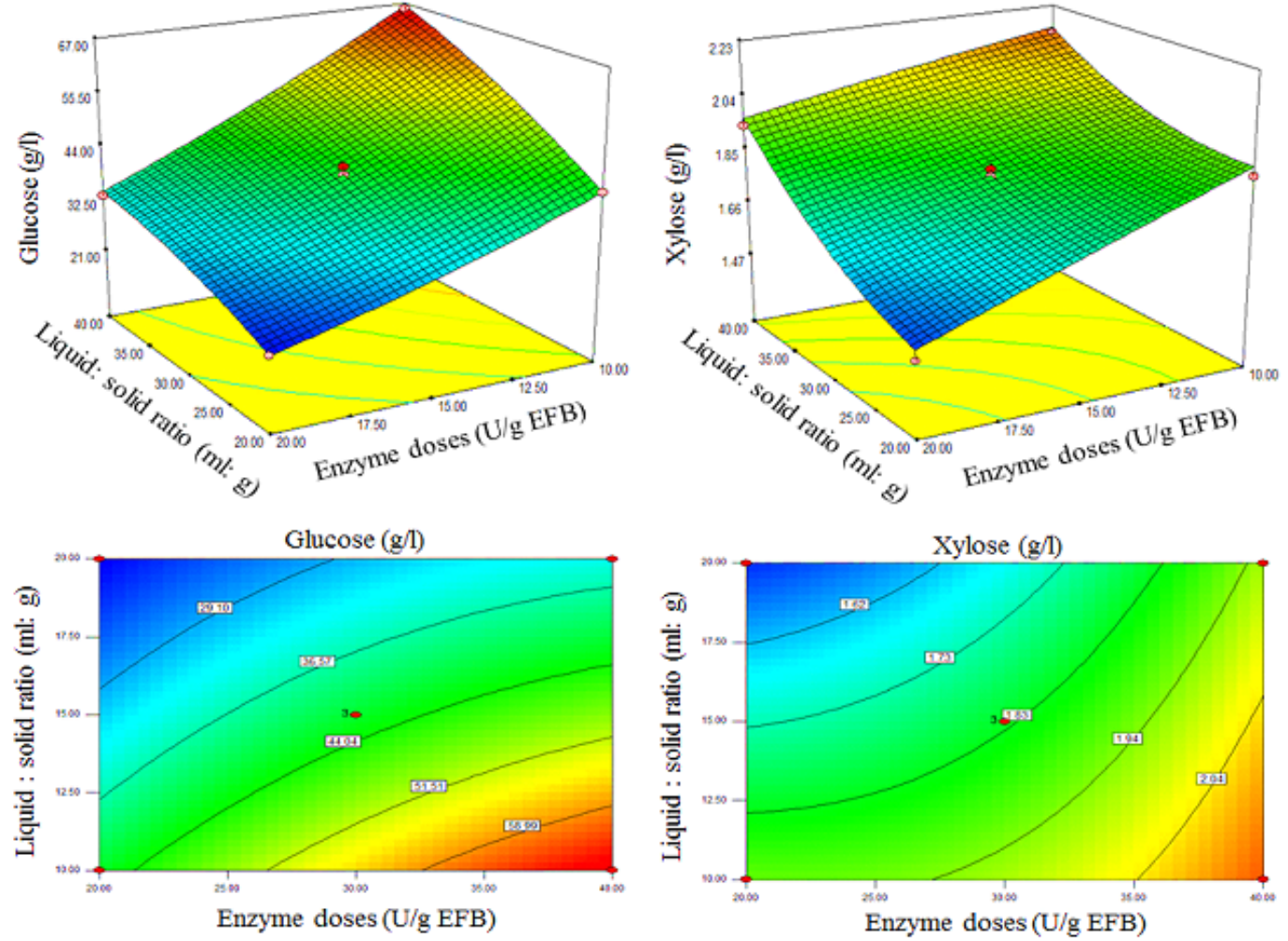

Figure 2

Effect of enzyme dose and liquid to solid ratio on glucose and xylose productions from alkaline peroxide pretreated oil palm empty fruit bunch 

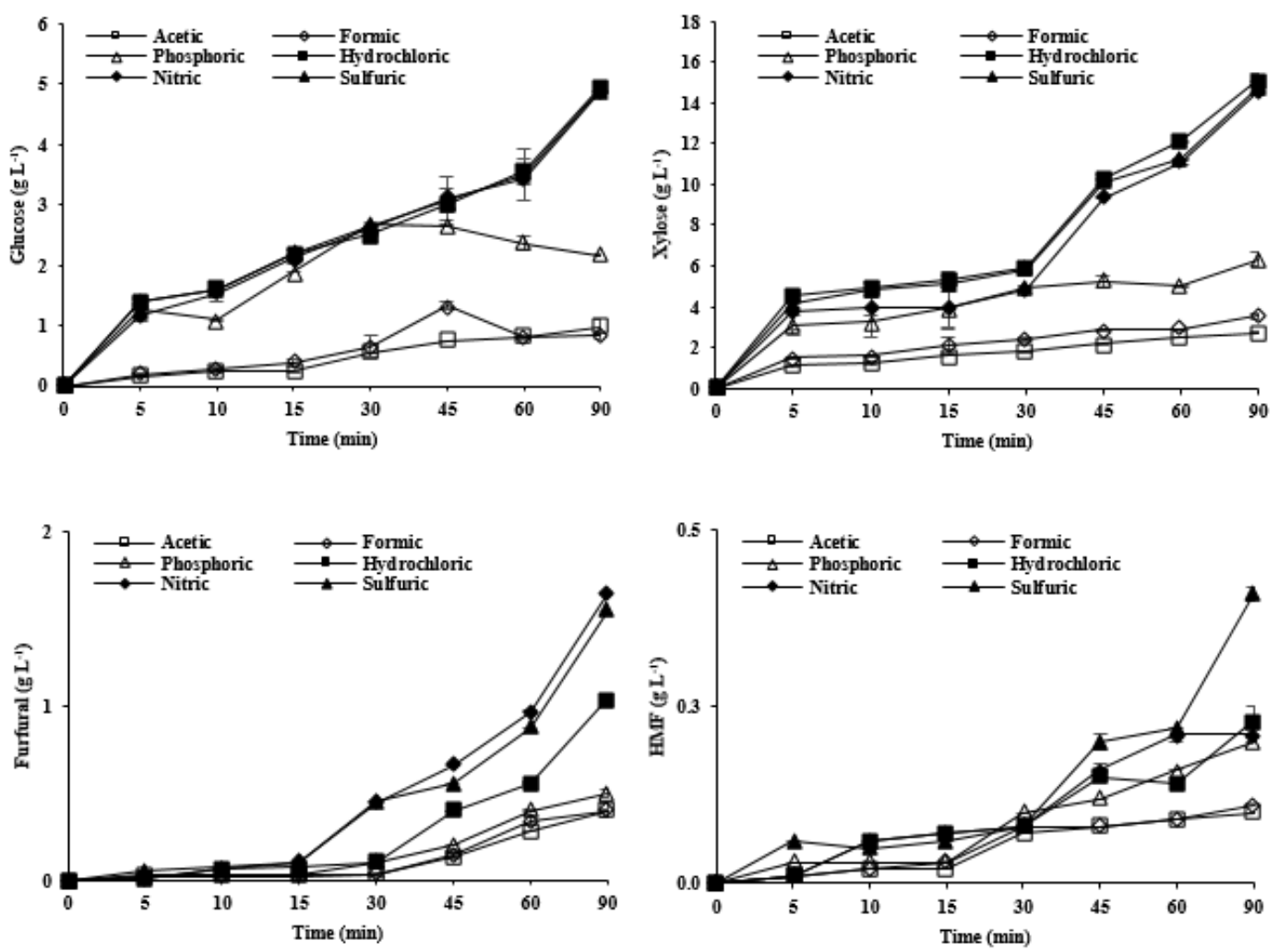

Figure 3

Sugars and by-products productions from alkaline peroxide pretreated empty fruit bunch by different acids at $120^{\circ} \mathrm{C}$ 

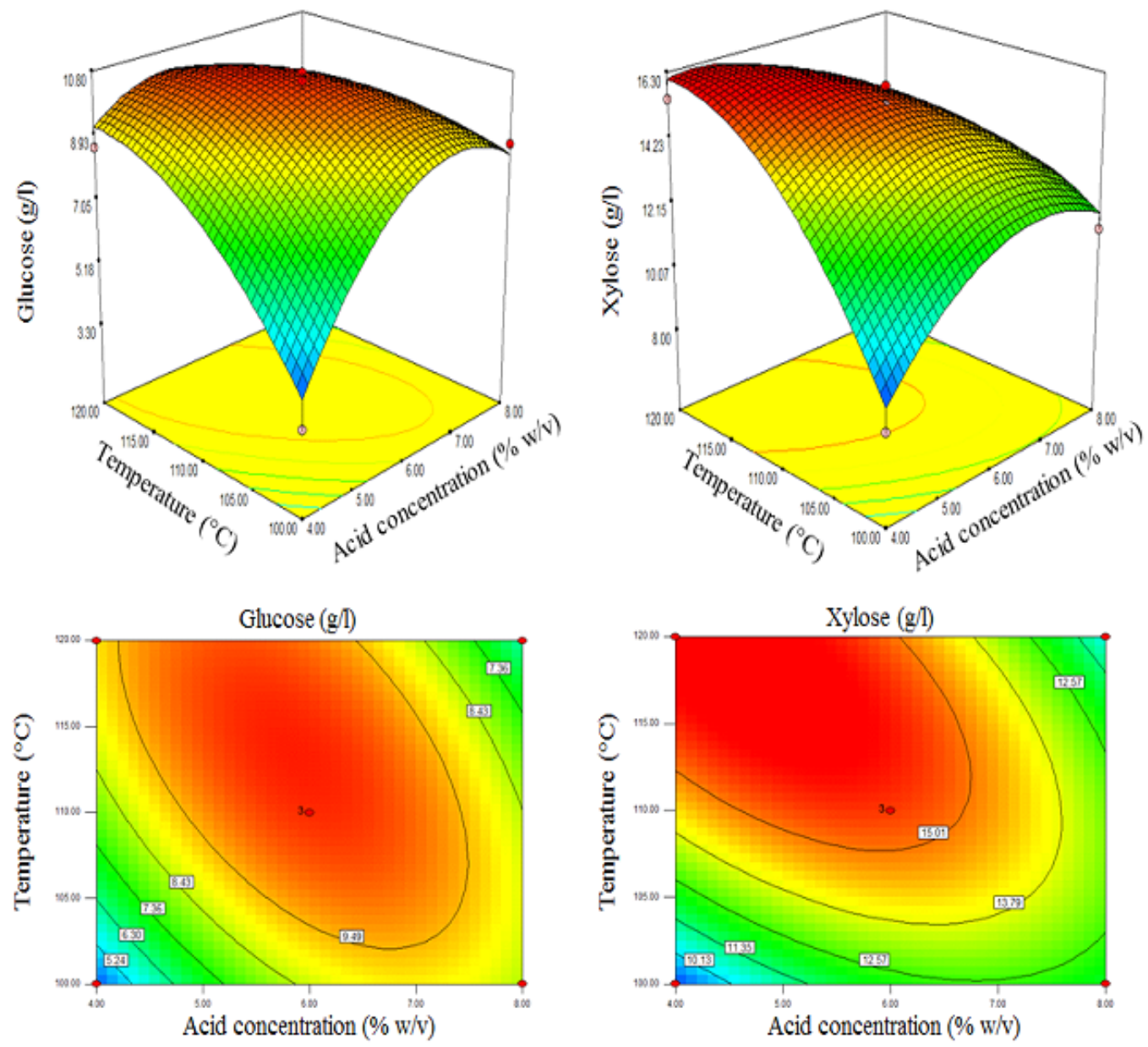

Figure 4

Effects of hydrochloric acid concentration and temperature on glucose and xylose productions from alkaline peroxide pretreated empty fruit bunch 

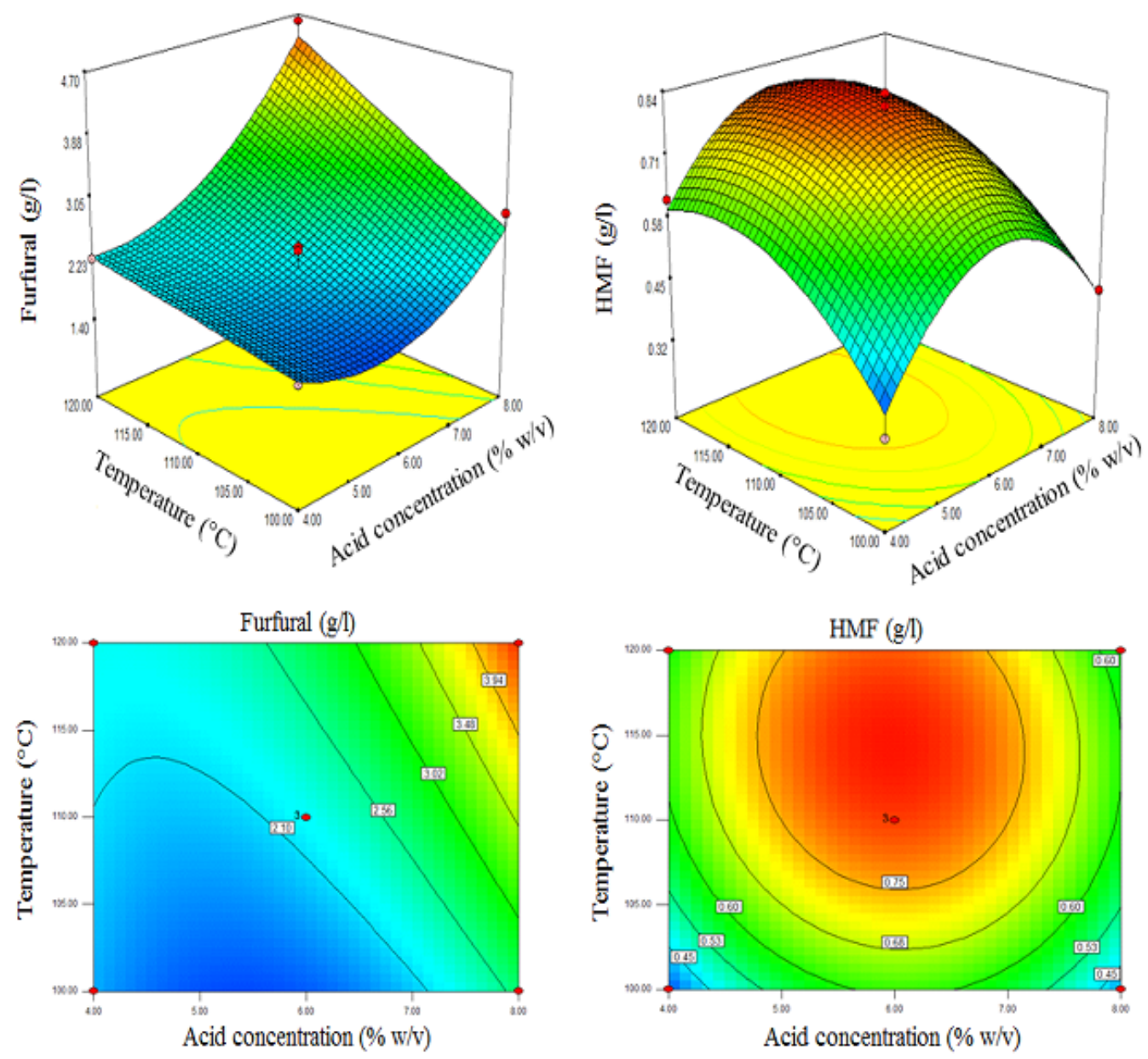

Figure 5

Effects of hydrochloric acid concentration and temperature on furfural and HMF productions from alkaline peroxide pretreated empty fruit bunch 